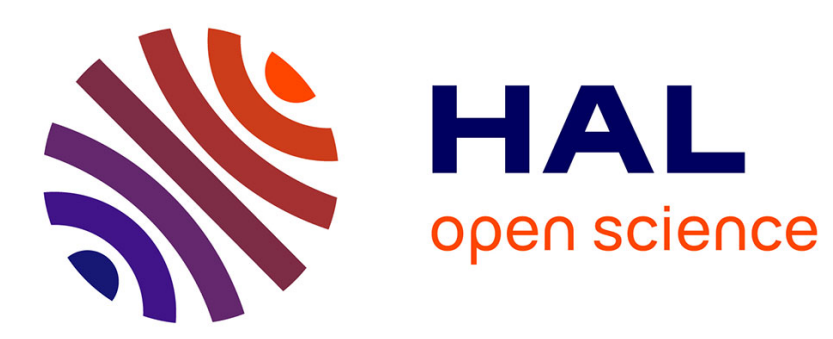

\title{
Literature review of the decision--making determinants related to the influenza vaccination policy
}

Maria-Laura Silva, Lionel Perrier, Jean Marie Cohen, Anne Mosnier, John

Paget, Hans-Martin Späth

\section{- To cite this version:}

Maria-Laura Silva, Lionel Perrier, Jean Marie Cohen, Anne Mosnier, John Paget, et al.. Literature review of the decision--making determinants related to the influenza vaccination policy. 2013. halshs00808536

\section{HAL Id: halshs-00808536 \\ https://shs.hal.science/halshs-00808536}

Preprint submitted on 5 Apr 2013

HAL is a multi-disciplinary open access archive for the deposit and dissemination of scientific research documents, whether they are published or not. The documents may come from teaching and research institutions in France or abroad, or from public or private research centers.
L'archive ouverte pluridisciplinaire HAL, est destinée au dépôt et à la diffusion de documents scientifiques de niveau recherche, publiés ou non, émanant des établissements d'enseignement et de recherche français ou étrangers, des laboratoires publics ou privés. 
Literature review of the decision-making determinants related to the influenza vaccination policy

Maria Laura Silva, Lionel Perrier, Jean Marie Cohen, Anne Mosnier, John Paget, Hans Martin Spath 


\section{GATE Groupe d'Analyse et de Théorie Économique Lyon-St Étienne}

93, chemin des Mouilles 69130 Ecully - France

Tel. +33(0)4 72866060

Fax $+33(0) 472866090$

6, rue Basse des Rives 42023 Saint-Etienne cedex 02 - France

Tel. +33 (0)4 77421960

Fax. +33 (0)4 77421950

Messagerie électronique / Email : gate@gate.cnrs.fr

Téléchargement / Download : http://www.gate.cnrs.fr - Publications / Working Papers 


\section{LITERATURE REVIEW OF THE DECISION MAKING DETERMINANTS RELATED TO THE INFLUENZA VACCINATION POLICY}

Maria Laura Silva ${ }^{\mathrm{a}, \mathrm{b}}$, Lionel Perrier ${ }^{\mathrm{a}, \mathrm{c}}$, Jean Marie Cohen ${ }^{\mathrm{b}}$, Anne Mosnier ${ }^{\mathrm{b}}$, John Paget $^{\mathrm{d}}$, Hans Martin Spath ${ }^{\mathrm{e}}$

a Université de Lyon, Lyon, F-69007, France ; CNRS, GATE Lyon Saint-Etienne, Ecully, F69130, France ; Université Lyon 2, Lyon, F-69007, France.

b OPEN ROME; Coordination Nationale des Groupes Régionaux d’Observation de la Grippe, Réseau des GROG, Paris France

${ }^{\mathrm{c}}$ Cancer and Environment department, Cancer Centre Léon Bérard, Lyon, France.

${ }^{\mathrm{d}}$ Netherlands Institute For Health Services Research (NIVEL), Utrecht, The Netherlands

${ }^{\mathrm{e}}$ University of Lyon; University Claude Bernard, Lyon 1 EAM 4128, Lyon, France 


\begin{abstract}
Background: Seasonal influenza concerns the worldwide population every year, whilst pandemic influenza is an unpredictable threat. Due to an important socioeconomic impact, mitigation measures must be specified. Governments elaborate vaccination policy based on scientific evidence. However, this process is, in general, not transparent.

Objectives: To study the decision-making process related to the influenza vaccination policy, identifying the actors involved, the decisions made and describing the information used by type and level of importance.

Methods: Six major databases were searched in seven languages, without time limit, using keywords related to influenza vaccination, decision-making and health policy. Titles and abstracts were screened according to three established criteria. Selected articles were analysed and compared against a checklist for context, stakeholders and evidence.

Results: 111 articles were retrieved since the 1990s, most of them (40\%) were conducted in the USA. The decision-making process mainly concerned vaccination strategies (53\%) and pandemic preparedness (28\%). Stakeholders were identified at an institutional, production and consumer level. Evidence used by policy-makers was similar (e.g. logistics of vaccines), but the factors influencing were different (e.g. social conditions).

Conclusion: Considering the imminent risk of socio-economic disruption and media pressure, the pandemic threat needs to be integrated into an analysis of decision making processes regarding seasonal influenza vaccination.
\end{abstract}

KEYWORDS: decision-making, influenza vaccination, public health policy

JEL Classification: I18 


\section{INTRODUCTION}

In annual influenza epidemics, 5-15\% of the world population is affected with acute respiratory infection. Most people with the illness recover quickly, but children, elderly and those with chronic medical conditions are at higher risk for complications and sometimes death (OECD, 2011). According to the World Health Organization (WHO) these annual epidemics result in 3-5 million cases of severe illness and 250-500 thousand deaths worldwide. In terms of costs of healthcare, lost days of work and education, and social disruption are between USD 1 million and USD 6 million per 100,000 inhabitants yearly in industrialized countries (WHO, 2009). In the case of influenza pandemic, this impact could be increased by a high order of magnitude (Chick et al., 2008).

Policy-makers at all levels are usually interested in the socioeconomic impact of influenza, in order to better allocate resources for strategies of prevention and control, such as vaccines (Jefferson and Demicheli, 1998). Although vaccines could be considered effective (Germann et al., 2006; Osterholm et al., 2012) and cost-effective (Nichol et al., 1994), their suboptimal allocations can be attributed to misaligned incentives of policy-makers (Chick et al., 2008). Nevertheless, there is a lack of studies evaluating the decision-making process regarding the supply chain of vaccines and vaccination strategies during seasonal or pandemic contexts. This situation leads to the main question of our research: which kind of evidence do policymakers use when facing decisions concerning influenza?

The objective of this literature review is to emerge studies evaluating the decision-making process related to the influenza vaccination policy. The secondary objectives are to identify the actors involved and their role in the process, to describe the information used in decision making for vaccination policy, to group by type of information, to classify by level of importance, to describe the decisions made. 


\section{METHODS}

\section{Search definitions}

Keywords were chosen based on the terms of the Medical Subject Heading (MeSH). They were combined according to the main objective of this literature review: study the decision making process of influenza vaccination policy:

- Influenza vaccines

- Vaccinations AND Influenza

- Decision support techniques OR decision making

- Policy OR public health OR public health administration OR health policy OR public policy OR Management

No limits of period or location delimitation were applied.

Main electronic databases were use:

- Web of Science (consists on seven multidisciplinary databases containing information gathered from scholarly journals, books, reports, conferences coverage in the sciences, social sciences, arts and humanities)

- Google Scholar (includes most peer-reviewed online journals of Europe and America's largest scholarly publishers, plus scholarly books and other non-peer reviewed journals)

- Pubmed (includes citations for biomedical articles from MEDLINE and life science journals)

- EconLit (contains abstracts of the international economic literature and related fields: economy, growth, development and technological change, demography, econometrics, finance and money, mathematical and quantitative methods, natural resources)

- Euronheed (network built on the foundations of two databases: 1-NHS EED: UK's National Health System Economic Evaluation Database and 2-CODECS: Connaissances et Décision en Économie de la Santé French database of Knowledge and Decision in Health Economics; it is also composed by other five European databases of economic evaluation: Germany, Italy, Netherlands, Nordic, Spain)

- Cochrane (collection of databases in medicine and other healthcare specialties; database of systematic reviews and meta-analyses, which summarize and interpret the results of medical research)

References without abstracts and which full text was written in other language different from English, French, Spanish, German, Italian and Portuguese were excluded. 
Specific databases such as the Centers for Disease Control and Prevention's (CDC) reports or the World Health Organization (WHO) Bulletins were also searched.

\section{Criteria for inclusion and exclusion}

The articles retrieved had titles and abstracts screening according to criteria of inclusion and exclusion established.

\section{Inclusion criteria}

- Presence of macro ${ }^{1}$ level decision-making (at local, regional, national or international levels) regarding influenza vaccination programs (target groups, reimbursement...) and vaccines (formulation, stockpile, distribution, production, management...),

- Description of the actors involved in this decision,

- Description of the information used during the decision making process assessed.

\section{Exclusion criteria}

- Decisions made in meso or micro ${ }^{2}$ levels only, such as in hospitals, clinics or medical offices (relation between physicians and patients),

- Assessments of the willingness of people (general population, health care professionals, parents of children...) to get vaccinated or to accept recommendations or requirements about getting vaccinated,

- Modeling studies concerning past vaccination strategies adopted, or proposition of new strategies (optimal vaccination strategies),

- Economic evaluations (cost-benefit, cost-effectiveness, cost-of-illness, economic burden...) about vaccine efficacy/effectiveness and vaccination rate.

\section{Checklist for full text reading}

Articles selected to full text reading were checked according to the following list:

- What is the current context (influenza pandemic or seasonal, health system, politics, socio-demographic, economics)?

- Which decisions are under discussion (vaccination strategies and vaccines)?

\footnotetext{
1 From an organization perspective, the macro level refers to the actors and institutions within which the general organizational, regulatory frameworks and public health interventions of the broad health system are established and delivered, beyond national borders or not.

${ }^{2}$ From an organization perspective, the meso level refers to medium-sized units of service provision such as primary healthcare units or hospitals, and the micro level refers to interactions between individual patients and healthcare professionals.
} 
- who are the stakeholders (agencies providing recommendations about vaccines formulation and vaccination practices, policy-makers, manufacturers, healthcare professionals, patients -associations of high risk groups, anti-vaccine leagues-)?

- Which information influence decision-making (clinical evidence, burden of disease and epidemiological studies, economic evaluations)?

- Is there other factors influencing in decisions (experts opinions, pressure of groups target for vaccination, the media)?

- What is the relation between different stakeholders?

- What is decided?

Aiming to facilitate the analysis we classified each of the points highlighted in the checklist. This classification is based in the common characteristics of stakeholders and the impact of the information in the decision made.

\section{RESULTS}

\section{Articles inclusion}

Electronic databases search retrieved 4743 references. Based on the titles and abstracts, we excluded: 465 articles that did not have an abstract, 348 repeat texts and 3588 that did not meet the inclusion criteria. 342 articles were selected for full text reading. After a detailed reading of those, $231(68 \%)$ were excluded because they actually didn't match the inclusion criteria. Finally, we consider for analysis 111 articles (Annex 1).

Most of the articles excluded concerned local decision-making process (meso/micro level). They were mainly related to the personal choice of being vaccinated, especially target people such as children, elderly, immunosuppressed, patients with chronic diseases and healthcare professionals. Other articles excluded concerned decisions related to the influenza vaccines: composition, virus strains selection (virology and immunology assays), vaccine efficacy/effectiveness (randomized clinical trial, economic evaluations and modeling), adverse events of vaccines and vaccination rates. Decisions regarding solely antivirals policy were also excluded. 


\section{Period of publication}

Publication of articles ranged from year 1994 to 2012. Peaks of publication happened in the years with a remarkable event, such as a pandemic, vaccine disruption and ethical issues. Fifty seven percent ( $\mathrm{n}=63)$ of the articles included were published in the last three years (from 2009 to 2012). The possible reason is the pandemic human influenza (H1N1pdm09) happened in the year of 2009. Twenty five percent ( $n=28)$ of the articles were published in 2005 and 2006. In this case, a shortage of vaccine supply in 2005 seasonal influenza in the US was in the spotlights together with ethical issues of equitable access, distribution and allocation of existing vaccine resources. Four publications related to epizootic pandemic influenza H5N1 of 2003 were included from 2003 and 2004

\section{Location}

The United States was the most common local chosen by authors in local, state or federal levels $^{3}(n=44,40 \%)$. The comparison between vaccination policies in the US and European countries, Canada, or Latin America was the object of other 7 studies.

Eight studies conducted in Canada mostly evaluated pandemic preparedness plan and compared national influenza vaccine strategies to other countries around the world.

Twenty six percent of the studies $(n=29)$ did not focus on a particular location for the analysis, but made a global comparison about vaccination policies and pandemic preparedness plan. European countries (France, Germany, Italy, Israel, Netherlands) were selected for twelve studies and one comparison with Canada and US.

Representing the east side of the globe, Australia $(n=7)$, India $(n=2)$ and Hong Kong $(n=1)$ evaluated their vaccination strategy and pandemic preparedness plan. Table 1 details the location where the studies were conducted.

\footnotetext{
3 The US government is responsible for the buying and distribution of influenza vaccines in the US. This work is largely carried out by the Centers for Disease Control and Prevention. As a result, there are many US publications in the public domain regarding this issue which appear every year. For example, the CDC gives a regular update on vaccine supplies each winter. However, this is not comparable to other countries where other procedures are at work and supply is often left more to the private market.
} 
Table 1: Location where studies were conducted

\begin{tabular}{|c|c|c|c|}
\hline Location & Decisions made & $\begin{array}{l}\text { Nb of } \\
\text { studies }\end{array}$ & $\#$ \\
\hline Australia & $\begin{array}{l}\text { Vaccine prioritization, purchasing } \\
\text { Pandemic preparedness plan }\end{array}$ & 7 & $25,26,37,48,78,85,132$ \\
\hline $\begin{array}{l}\text { Canada } \\
\text { Canada and others } \\
\text { (Australia, France, Mexico, } \\
\text { Sweden, US, UK) }\end{array}$ & $\begin{array}{l}\text { Vaccine production, prioritization, } \\
\text { purchasing } \\
\text { Pandemic preparedness plan } \\
\text { Vaccination strategy } \\
\text { Pandemic preparedness plan }\end{array}$ & 6 & $\begin{array}{l}11,69,97,102,108,125 \\
41,131\end{array}$ \\
\hline China/ Hong Kong & Pandemic preparedness plan & 1 & 70 \\
\hline EU, Canada, US & $\begin{array}{l}\text { Vaccine virus selection, } \\
\text { prioritization } \\
\text { Vaccination strategy } \\
\text { Pandemic preparedness plan } \\
\text { Vaccine production, prioritization, } \\
\text { distribution }\end{array}$ & 1 & $2,31,34,59,74,100,117$ \\
\hline France & Vaccination strategy & 1 & 38 \\
\hline Germany & Pandemic preparedness plan & 1 & 115 \\
\hline India & Pandemic preparedness plan & 2 & 42,66 \\
\hline Israel & Vaccine purchasing & 1 & 14 \\
\hline Italy & Vaccine prioritization & 1 & 23 \\
\hline Netherlands & Pandemic preparedness plan & 1 & 109 \\
\hline USA & $\begin{array}{l}\text { Vaccine virus selection, } \\
\text { development, production, } \\
\text { prioritization, purchasing, supply } \\
\text { Vaccination strategy } \\
\text { Pandemic preparedness plan }\end{array}$ & 51 & $\begin{array}{l}1,8,12,15,16,18,19,20, \\
22,30,36,39,45,46,47,49, \\
50,51,52,55,57,58,61,63, \\
67,68,72,73,76,77,80,82, \\
83,84,86,87,88,89,91,98, \\
99,113,114,121\end{array}$ \\
\hline $\begin{array}{l}\text { USA and others } \\
\text { (Canada, EU, UK, Latin } \\
\text { America) }\end{array}$ & $\begin{array}{l}\text { Vaccination strategy } \\
\text { Pandemic preparedness plan }\end{array}$ & 7 & $93,103,54,101,44,104,124$ \\
\hline $\begin{array}{l}\text { Global } \\
\text { (no country specified) }\end{array}$ & $\begin{array}{l}\text { Vaccine virus selection, } \\
\text { development, production, } \\
\text { prioritization, purchasing, supply } \\
\text { Pandemic preparedness plan }\end{array}$ & 29 & $\begin{array}{l}9,90,92,94,110,119,3,4, \\
5,6,7,10,13,17,24,28,29 \\
32,53,56,60,62,64,71,75, \\
81,96,105,107\end{array}$ \\
\hline
\end{tabular}

\section{Current context}

In order to classify the articles found, we use the assumptions driven by the virus-centric thinking which leads to dichotomizing influenza into "pandemic" and "seasonal", according to the genetic mutations of the flu virus (Doshi, 2011). On this basis, we found that 81 articles were related to pandemic and 24 to seasonal flu. Some articles $(n=6)$ discussed how seasonal influenza surveillance systems could be used in pandemic situations, giving emphasis on both seasonal and pandemic contexts. Half of the 111 articles included, target the preparedness plan for influenza pandemic, before, during and after the occurrence of a pandemic. Ancient and recent pandemics $(1918,1957,1968,2009)$ are taken as examples of what has been learned and what was improved meanwhile. 


\section{Stakeholders}

The noun "stakeholder" receives different definitions according to the environment in where it is used. In our research, we adopted the business concept retrieved at the Collins Dictionary online (Collins, 2012) which defines stakeholder as: "a person, group, organization, member or system that affects or can be affected by a project or event".

Stakeholder cans also be used as an adjective that matches with our study: "of or relating to policies intended to allow people to participate in and benefit from decisions made by enterprises which they have a stake". Stakeholders, related to influenza vaccination policy, who participate in and benefit from decisions made by health organizations which they have a stake were identified and classified in the following groups:

- Institutional level:

○ International organizations: WHO, World Bank,

Regional departments: EuroWHO, Pan American Health Organization (PAHO), (European Center for Disease Prevention and Control (ECDC),

o National institutes: Advisory Committee on Immunization Practices (ACIP), Food and Drug Administration (FDA), CDC, Australian Health Protection Committee (AHCPR),

○ Governments (Ministry of Health, Health department), National/federal, Province/state/territory, local,

- Production level (market forces):

○ Manufacturers of vaccines,

- Healthcare providers: insurance companies, clinics, hospitals,

○ Healthcare workers, professionals: nurses, pharmacists, physicians,

- Consumers level:

○ General public.

\section{Information influencing decisions and other factors of impact}

Main information and factors influencing decisions were identified in the articles selected. Fourteen categories were established and ranked in Table 2 according to its impact on the decision. 
Table 2: Main information and factors influencing the decision making process regarding influenza vaccination policy

\begin{tabular}{|c|c|c|}
\hline $\begin{array}{l}\text { Main information, } \\
\text { number of articles } \\
\text { related }\end{array}$ & Information detailed & $\#$ \\
\hline $\begin{array}{l}\text { Logistics of vaccines } \\
\mathrm{n}=46\end{array}$ & $\begin{array}{l}\text { Virus selection/composition } \\
\text { Development } \\
\text { Production/manufacturing } \\
\text { Industrial capacity } \\
\text { Prioritization/rationing } \\
\text { Purchase/order/demand } \\
\text { Distribution/supply/allocation } \\
\text { Delivery } \\
\text { Social acceptance } \\
\text { Recommendation } \\
\text { Mandatory } \\
\text { Mass campaign } \\
\text { Programmatic administration }\end{array}$ & $\begin{array}{l}2,4,6,8,9,10,11,13,14,16,17,20,30,33 \\
38,39,45,50,51,53,57,58,62,63,64,68 \\
71,72,73,74,76,77,81,83,89,91,94,97 \\
98,103,105,107,108,114,115,125\end{array}$ \\
\hline $\begin{array}{l}\text { Influenza surveillance } \\
\text { data } \\
\mathrm{n}=41\end{array}$ & $\begin{array}{l}\text { Flu activity } \\
\text { Transmissibility } \\
\text { Geographic distribution } \\
\text { Time course of pandemic }\end{array}$ & $\begin{array}{l}6,7,8,11,13,17,20,22,23,24,26,29,32 \\
36,37,44,51,55,56,63,66,70,71,72,73, \\
76,82,83,84,86,90,93,97,98,107,109 \\
113,114,115,119,126\end{array}$ \\
\hline $\begin{array}{l}\text { Vaccines scientific } \\
\text { studies } \\
\mathrm{n}=37\end{array}$ & $\begin{array}{l}\text { Randomized clinical trials: vaccine } \\
\text { efficacy } \\
\text { effectiveness } \\
\text { safety } \\
\text { clinical evidence, scientific, } \\
\text { observational studies } \\
\text { immunization }\end{array}$ & $\begin{array}{l}1,4,11,13,14,28,30,31,32,33,34,36,37 \\
38,44,45,46,53,56,58,59,61,67,69,73 \\
75,78,81,85,86,93,99,100,101,102,104 \\
105\end{array}$ \\
\hline $\begin{array}{l}\text { Local status, social } \\
\text { conditions } \\
\mathrm{n}=26\end{array}$ & $\begin{array}{l}\text { Logistics for pandemic response } \\
\text { Education } \\
\text { Politics (political willingness) } \\
\text { Economy } \\
\text { Media } \\
\text { Transparency }\end{array}$ & $\begin{array}{l}18,28,39,41,42,44,45,50,53,54,61,80 \\
85,87,88,89,90,91,97,99,107,113,115, \\
117,121,125\end{array}$ \\
\hline $\begin{array}{l}\text { Epidemiology } \\
\mathrm{n}=25\end{array}$ & $\begin{array}{l}\text { Morbidity } \\
\text { Mortality } \\
\text { Severity }\end{array}$ & $\begin{array}{l}3,8,10,11,13,15,18,23,24,30,33,36,41 \\
49,54,56,71,73,74,81,84,92,109,115,132\end{array}$ \\
\hline $\begin{array}{l}\text { Ethics } \\
\mathrm{n}=24\end{array}$ & $\begin{array}{l}\text { Professional judgments } \\
\text { Cultural requirements } \\
\text { Willingness to be vaccinated } \\
\text { Legal/juridical approaches } \\
\text { Philosophy grounds }\end{array}$ & $\begin{array}{l}5,11,16,19,42,46,48,51,58,67,69,70,76 \\
78,81,87,89,92,93,99,101,102,103,121\end{array}$ \\
\hline $\begin{array}{l}\text { Guidelines } \\
\mathrm{n}=24\end{array}$ & $\begin{array}{l}\text { Reviews, reports, records, } \\
\text { publications, website docs } \\
\text { Protocols, checklist } \\
\text { Recommendation }\end{array}$ & $\begin{array}{l}3,19,25,26,30,31,34,41,47,50,54,55,58 \\
66,68,75,85,97,102,110,111,112,124,131\end{array}$ \\
\hline $\begin{array}{l}\text { Virological diagnosis } \\
\mathrm{n}=19\end{array}$ & $\begin{array}{l}\text { Serological } \\
\text { Antigenic strains } \\
\text { Laboratory capacity }\end{array}$ & $\begin{array}{l}6,13,23,28,29,38,44,53,57,64,66,71,93 \\
96,100,104,114,119,126\end{array}$ \\
\hline
\end{tabular}




\begin{tabular}{|l|l|l|}
\hline $\begin{array}{l}\text { Main information, } \\
\text { number of articles } \\
\text { related }\end{array}$ & Information detailed & $\#$ \\
\hline $\begin{array}{l}\text { Financial resources } \\
\mathrm{n}=18\end{array}$ & $\begin{array}{l}\text { Funding } \\
\text { Budget }\end{array}$ & $\begin{array}{l}10,14,25,29,49,51,62,64,74,77,97,98, \\
100,101,102,104,114,119\end{array}$ \\
\hline $\begin{array}{l}\text { Registries } \\
\mathrm{n}=16\end{array}$ & $\begin{array}{l}\text { Past pandemic information } \\
\text { History } \\
\text { Lessons learned }\end{array}$ & $\begin{array}{l}8,11,12,13,15,26,60,62,63,68,86,93,99, \\
108,110,132\end{array}$ \\
\hline $\begin{array}{l}\text { Models } \\
\mathrm{n}=14\end{array}$ & $\begin{array}{l}\text { Mathematical } \\
\text { Decision policy analysis }\end{array}$ & $\begin{array}{l}6,7,11,12,15,16,20,24,38,51,52,96,108, \\
109\end{array}$ \\
\hline $\begin{array}{l}\text { Experts advices } \\
\mathrm{n}=13\end{array}$ & $\begin{array}{l}\text { Advisory groups } \\
\text { Scientific committees }\end{array}$ & $2,5,14,30,47,55,58,60,61,77,99,109,121$ \\
\hline $\begin{array}{l}\text { Economic studies } \\
\mathrm{n}=13\end{array}$ & $\begin{array}{l}\text { Burden of influenza } \\
\text { Cost-benefit analysis } \\
\text { Cost-effectiveness analysis } \\
\text { Risk analysis } \\
\text { Uncertainty }\end{array}$ & $\begin{array}{l}9,11,15,33,54,59,81,93,100,105,109, \\
117,121\end{array}$ \\
\hline $\begin{array}{l}\text { Demographics } \\
\mathrm{n}=5\end{array}$ & \begin{tabular}{l} 
Population size and age \\
\hline
\end{tabular} & $19,68,91,108,125$ \\
\hline
\end{tabular}

\section{Decisions made}

Two main categories of decisions were established: (1) vaccination strategy and (2) pandemic preparedness plan. Vaccination strategy is analyzed in both pandemic and seasonal contexts. Although vaccination strategy can be part of a pandemic preparedness plan, it is here analyzed separately (Annex 2).

1) Vaccine strategy $(n=70,53 \%)^{4}$

the steps of a vaccination strategy do not depend on the context (pandemic or seasonal), and it corresponds to the pharmaceutical cycle of the vaccine, from its conception, through logistics of distribution until consumption. Decisions are specific to each stage of this cycle and regards the main choices described below:

a) Virus selection, composition or formulation of the vaccine: influenza strains to include, trivalent vs. quadrivalent, pandemic...

b) Development of the biological product (requires $R \& D^{5}$ ) use of adjuvants, eggs vs. cell culture, age restrictions...

\footnotetext{
${ }^{4}$ See annex 2.

${ }^{5}$ The term R\&D or research and development refers to a specific group responsible for develop new products;
} 
c) Production, manufacturing (requires approval by regulatory institutes) quantity to produce, consider reimbursement

d) Purchase, ordering amount to purchase, prioritization of groups target (age, medical condition...), allocation of resources, mandatory vaccination (healthcare workers, military...)

e) Distribution from manufacturer to the purchaser or from centralized to decentralized levels logistics of delivery, transportation of thermosensitive biologicals

f) Vaccine intake incitation for vaccination (universal free vaccine, reimbursement, mandate), allocation of healthcare expenditures.

This final step will not be analyzed once it concerns a lower level of decision (patient level, social acceptance of getting vaccines), and we are interested in higher levels (policy level).

2) Pandemic Preparedness Plan $(n=37,28 \%)^{6}$

Generally, when policy makers elaborate an influenza pandemic preparedness plan, a vaccination strategy is included as one of the measures for containing pandemic virus spread. Other measures for control are also included in the plan, such as social distance and isolation (closing schools, quarantine), disinfection, antivirals promotion. Although these measures are usually adopted together with a vaccination strategy, we are only focusing on the latter. The most important difference between vaccination strategies during seasonal or pandemic context is the situation of risk faced by policy makers. Concepts of uncertainty, risk management and emergency actions are usually adopted.

Information used in decisions made in the contexts of seasonal or pandemic influenza is similar, but the factors influencing were very different. A routine situation of annual influenza policy in the case of a seasonal flu becomes an uncertainty context of risk management when a pandemic is declared.

\footnotetext{
${ }^{6}$ See annex 2.
} 


\section{DISCUSSION}

This literature review identified the contexts where influenza policy is done and the information used. Most of the publications referred to decisions made in the context of pandemic influenza, due to the imminent risk of socio-economic disruption and media pressure. The other articles analyze if measures adopted for seasonal influenza can be used in case of pandemic. Main factors influencing or information used when elaborating plans for control measures against influenza seasonal or pandemic are described below.

\section{Population target for vaccination}

The first issue to be considered when planning for a seasonal or pandemic influenza is the target population for vaccination. This is based on assumptions of the group that might get most benefit from vaccination. Studies assessing vaccine effectiveness, economic evaluations, type of influenza epidemiology (morbi-mortality) and data about vaccination rates are useful to justify choices made (Lee et al., 2012; Lipsitch et al., 2011).

\section{Vaccines formulation and production}

WHO recommends annually the virus composition of seasonal influenza vaccine for both northern and southern hemispheres. These recommendations are based on surveillance data from sentinel influenza networks worldwide and antigenic virological information provided during the whole year by the National Influenza Centres responsible for virus identification, subtyping and characterization. For pandemic vaccines, once the virus is isolated, recommendations about the antigenic characteristics are provided. Manufacturers have then some months before the winter season, where influenza is epidemic, to make available a sufficient amount of vaccines for supplying the world demand. Commercial interest associated with studies of vaccine effectiveness in different age groups and antigenic match (between the circulating virus and the current vaccine composition) encourage manufacturers to promote new types of vaccines. These vaccines can present different formulations from the ones recommended by WHO, target a specific age group, or can be available by nasal administration, for instance (Kamradt-Scott, 2012; Yaesoubi and Cohen, 2011).

\section{Communication}

Communication between stakeholders involved in the decision making process was seen to be very important for the success of the vaccination policy. Collaboration between different levels of governance (federal, state/regional, local), health institutes, experts and 
manufacturers enable robustness of information produced and evidence used in the policy. Transparency when involving health care professionals and patients in the process of policy elaboration is essential to guarantee compliance. The media should be seen as an alliance, so information given must also be transparent and retrieved from confident sources (Gazmararian et al., 2006; Ringel et al., 2009).

\section{Ethics}

Policy implementation is certainly enhanced when decision makers are perceived to act in a responsible and ethical manner. Healthcare professionals have rights and obligations that must be taken into account, but during a pandemic the individual rights are questionable in the benefit of the society. This polemic statement is discussed in some of the articles included, and contradictory opinions are given (Dupras and Williams-Jones, 2012; Monto et al., 2011).

\section{Implications}

This literature review did not retrieve any publication conducted in France that evaluated the decision process regarding influenza policy with policy makers involved. Few studies conducted in the US and Canada reported findings obtained after surveys or workshops promoted with the objective of improving the seasonal influenza plan and the preparedness plan for pandemic influenza. According to these studies, feedbacks of the workshops were positive and changes were successfully approved and adopted by local vaccination policies. However, studies surveying patients and healthcare professional against vaccination were not found (Doxtator et al., 2004; Neudorf et al., 2003; Oxford et al., 2005; Stroud et al., 2011).

\section{CONCLUSION}

Articles included in this literature review were retrieved since the 1990s until 2012. Most of them were conducted in the North America (59\%) and Europe (11\%). Stakeholders were identified as institutional, production and consumers levels. Decisions were made in both seasonal and pandemic context regarding several levels of the vaccine lifecycle chain. Each step of this chain required specific decisions, which were based on similar evidence in different countries. However, no standard process among locations was observed. External factors, such as the health system, economic context and the resources allocated influenced on the decision making process. 
Further studies based on this literature review will consist on the elaboration of questionnaires and a semi-structured interview. These could be applied to the stakeholders involved in the vaccination policy here identified, for example by comparing different locations or levels of decisions, and groups pro and against vaccination. Evidences and information used may be stated to the respondents, for verifying the existence of standard procedures or justifying such a position regarding vaccination. Local peculiarities of French health system, the political and economic context and in case of a pandemic or not must be taken into account. After validation and data collection in France a second phase is planned.

Questionnaires and the interview could be adapted to stakeholders located in the Netherlands. Local details would be considered. Data collected in France would be compared with Dutch data. Vaccination policies and the opinions of different stakeholders within and between countries would be analyzed. Future findings could be used as another source of information for changes and improvement of the existing vaccination policy in both countries.

\section{ACKNOWLEDGEMENTS}

The research leading to these results has received doctoral grant support from OPENROME and CIENCIAS SEM FRONTEIRAS.

\section{REFERENCES}

Chick, S.E., Mamani, H., Simchi-Levi, D., 2008. Supply Chain Coordination and Influenza Vaccination. Operations Research 56, 1493-1506.

Collins, 2012. English Dictionary [WWW Document]. Definition of "stakeholder". URL http://www.collinsdictionary.com/dictionary/english/stakeholder?showCookiePolicy=true (accessed 2.28.03).

Doshi, P., 2011. The elusive definition of pandemic influenza. Bull World Health Organ 89, $532-538$.

Doxtator, L.A., Gardner, C.E., Medves, J.M., 2004. Responding to pandemic influenza - A local perspective. Canadian Journal of Public Health-Revue Canadienne De Sante Publique $95,27-31$.

Dupras, C., Williams-Jones, B., 2012. The expert and the lay public: reflections on influenza A (H1N1) and the risk society. Am J Public Health 102, 591-5.

Gazmararian, J.A., Orenstein, W.A., Wortley, P., Buehler, J.W., Elon, L., Koplan, J.P., Schild, L., Dixon, T., Weiss, P., Stephens, D.S., 2006. Preventing influenza: Vaccine systems and practices in the southeast. Public Health Reports 121, 684-694. 
Germann, T.C., Kadau, K., Longini, I.M., Jr, Macken, C.A., 2006. Mitigation strategies for pandemic influenza in the United States. Proc. Natl. Acad. Sci. U.S.A. 103, 5935-5940.

Jefferson, T., Demicheli, V., 1998. Socioeconomics of influenza, in: Nicholson, K.G., Webster, R.G., Hay, A.J. (Eds.), Textbook of Influenza. Blackwell Science, Malden, MA, pp. $541-7$.

Kamradt-Scott, A., 2012. Changing Perceptions of Pandemic Influenza and Public Health Responses. American Journal of Public Health 102, 90-98.

Lee, S., Golinski, M., Chowell, G., 2012. Modeling Optimal Age-Specific Vaccination Strategies Against Pandemic Influenza. Bulletin of Mathematical Biology 74, 958-980.

Lipsitch, M., Finelli, L., Heffernan, R.T., Leung, G.M., Redd, For the H1N1 Surveillance Group, S.C., 2011. Improving the evidence base for decision making during a pandemic: the example of 2009 influenza A/H1N1. Biosecurity and Bioterrorism: Biodefense Strategy, Practice, and Science 9, 89-115.

Monto, A.S., Black, S., Plotkin, S.A., Orenstein, W.A., 2011. Response to the 2009 pandemic: Effect on influenza control in wealthy and poor countries. Vaccine 29, 6427-6431.

Neudorf, C., Obayan, A., Anderson, C., Chomyn, J., 2003. A collaborative system-wide response to influenza outbreak management in Saskatoon Health Region. Canadian Journal of Public Health-Revue Canadienne De Sante Publique 94, 338-340.

Nichol, K.L., Margolis, K.L., Wuorenma, J., Von Sternberg, T., 1994. The efficacy and cost effectiveness of vaccination against influenza among elderly persons living in the community. The New England journal of medicine 331, 778-784.

OECD, 2011. Health at a Glance 2011: OECD indicators. OECD Publishing.

Osterholm, M.T., Kelley, N.S., Ballering, K.S., Manske, J.M., Leighton, T.R., Moore, K.A., 2012. The Compelling Need for Game-Changing Influenza Vaccines An Analysis of the Influenza Vaccine Enterprise and Recommendations for the Future.

Oxford, J.S., Manuguerra, C., Kistner, O., Linde, A., Kunze, M., Lange, W., Schweiger, B., Spala, G., De Andrade, H.R., Brena, P.R.P., Beytout, J., Brydak, L., De Stefano, D.C., Hungnes, O., Kyncl, J., Montomoli, E., De Miguel, A.G., Vranckx, R., Osterhaus, A., 2005. A new European perspective of influenza pandemic planning with a particular focus on the role of mammalian cell culture vaccines. Vaccine 23, 5440-5449.

Ringel, J.S., Moore, M., Zambrano, J., Lurie, N., 2009. Will routine annual influenza prevention and control systems serve the United States well in a pandemic? Disaster Med Public Health Prep 3 Suppl 2, S160-5.

Stroud, C., Altevogt, B.M., Butler, J.C., Duchin, J.S., 2011. The Institute of Medicine's Forum on Medical and Public Health Preparedness for Catastrophic Events: regional workshop series on the 2009 H1N1 influenza vaccination campaign. Disaster Med Public Health Prep 5, 81-6.

WHO, 2009. Worl Health Organization: Influenza (Seasonal). 
Yaesoubi, R., Cohen, T., 2011. Dynamic Health Policies for Controlling the Spread of Emerging Infections: Influenza as an Example. Plos One 6.

\section{Annex 1 - List of articles included by date of publication}

\begin{tabular}{|c|c|c|c|c|}
\hline$\#$ & Authors & Period of publica-ion & Country & Context \\
\hline 1 & Phillips & 2012 & USA & seasonal flu \\
\hline 2 & Mereckiene & 2012 & EU & pandemic flu \\
\hline 3 & Lee & 2012 & not specified & pandemic flu \\
\hline 4 & Kamradt-Scott & 2012 & not specified & pandemic flu \\
\hline 5 & Dupras & 2012 & \begin{tabular}{|l|} 
not specified \\
\end{tabular} & pandemic flu \\
\hline 6 & Ampofo & 2012 & not specified & seasonal flu \\
\hline 7 & Yaesoubi & 2011 & not specified & pandemic flu \\
\hline 8 & Stroud & 2011 & USA & pandemic flu \\
\hline 9 & $\mathrm{Ng}$ & 2011 & many in the world & both \\
\hline 10 & Monto & 2011 & \begin{tabular}{|l|} 
not specified \\
\end{tabular} & pandemic flu \\
\hline 11 & Moghadas & 2011 & Canada & pandemic flu \\
\hline 12 & Maciejewski & 2011 & USA & pandemic flu \\
\hline 13 & Lipsitch & 2011 & not specified & pandemic flu \\
\hline 14 & Levine & 2011 & Israel & pandemic flu \\
\hline 15 & Lee & 2011 & USA & pandemic flu \\
\hline 16 & Lee & 2011 & USA & pandemic flu \\
\hline 17 & Kamradt-Scott & 2011 & not specified & pandemic flu \\
\hline 18 & Hollingsworth & 2011 & USA & pandemic flu \\
\hline 19 & French & 2011 & USA & pandemic flu \\
\hline 20 & Chao & 2011 & USA & pandemic flu \\
\hline 22 & Burke & 2011 & USA & pandemic flu \\
\hline 23 & Ajelli & 2011 & Italy & pandemic flu \\
\hline 24 & Abellin & 2011 & not specified & pandemic flu \\
\hline 131 & Lam & 2011 & $\begin{array}{l}\text { Canada and others (Australia, Mexico, US, } \\
\text { UK) }\end{array}$ & pandemic flu \\
\hline 132 & Kelly & 2011 & Australia & pandemic flu \\
\hline 25 & Weeramantheri & 2010 & Australia & pandemic flu \\
\hline 26 & Spokes & 2010 & Australia & pandemic flu \\
\hline 28 & Rosner & 2010 & \begin{tabular}{|l|} 
not specified \\
\end{tabular} & seasonal flu \\
\hline 29 & Richard & 2010 & not specified & seasonal flu \\
\hline 30 & Rambhia & 2010 & \begin{tabular}{|l|} 
USA \\
\end{tabular} & pandemic flu \\
\hline 31 & Nicoll & 2010 & EU & pandemic flu \\
\hline 32 & Morens & 2010 & \begin{tabular}{|l|} 
not specified \\
\end{tabular} & pandemic flu \\
\hline 33 & Monto & 2010 & EU, Canada, USA & seasonal flu \\
\hline 34 & Mereckiene & 2010 & EU & seasonal flu \\
\hline 36 & Lee & 2010 & USA & pandemic flu \\
\hline 37 & Leask & 2010 & Australia & seasonal flu \\
\hline 38 & Labro & 2010 & France & both \\
\hline 39 & Kuehnert & 2010 & USA & pandemic flu \\
\hline 41 & Kendal & 2010 & $\begin{array}{l}\text { Canada and others (Australia, England, } \\
\text { France, Sweden, US) }\end{array}$ & pandemic flu \\
\hline 42 & Kakkar & 2010 & India & pandemic flu \\
\hline 44 & Dehner & 2010 & USA, Europe & pandemic flu \\
\hline 45 & Cho & 2010 & \begin{tabular}{|l|} 
USA \\
\end{tabular} & seasonal flu \\
\hline 46 & Bernstein & 2010 & USA & seasonal flu \\
\hline 47 & Berman & 2010 & USA & seasonal flu \\
\hline 48 & Bennett & 2010 & Australia & pandemic flu \\
\hline 49 & Alenzi & 2010 & USA & pandemic flu \\
\hline 50 & Zigmond & 2009 & USA & pandemic flu \\
\hline 51 & Schwartz & 2009 & \begin{tabular}{|l|} 
USA \\
\end{tabular} & pandemic flu \\
\hline 52 & Savoia & 2009 & USA & pandemic flu \\
\hline 53 & Sahni & 2009 & not specified & pandemic flu \\
\hline
\end{tabular}




\begin{tabular}{|c|c|c|c|c|}
\hline$\#$ & \begin{tabular}{|l|} 
Authors \\
\end{tabular} & Period of publica-ion & \begin{tabular}{|l|} 
Country \\
\end{tabular} & \begin{tabular}{|c|} 
Context \\
\end{tabular} \\
\hline 54 & Ropero-Alvarez & 2009 & USA, Canada and Latin America & seasonal flu \\
\hline 55 & Ringel & 2009 & USA & both \\
\hline 56 & O'Neil & 2009 & not specified & pandemic flu \\
\hline 57 & Mazanec & 2009 & USA & pandemic flu \\
\hline 58 & Kinlaw & 2009 & USA & pandemic flu \\
\hline 59 & Johansen & 2009 & EU & pandemic flu \\
\hline 60 & Hollenbeck & 2009 & not specified & pandemic flu \\
\hline 61 & Gallaher & 2009 & USA & pandemic flu \\
\hline 62 & Friede & 2009 & not specified & pandemic flu \\
\hline 63 & French & 2009 & USA & pandemic flu \\
\hline 64 & Flyborg & 2009 & not specified & pandemic flu \\
\hline 66 & Chawla & 2009 & India & pandemic flu \\
\hline 67 & Barnett & 2009 & USA & pandemic flu \\
\hline 68 & \begin{tabular}{|l|} 
Orenstein \\
\end{tabular} & 2008 & USA & both \\
\hline 69 & Mah & 2008 & Canada & seasonal flu \\
\hline 70 & Lam & 2008 & China & pandemic flu \\
\hline 71 & \begin{tabular}{|l|} 
Jennings \\
\end{tabular} & 2008 & not specified & pandemic flu \\
\hline 72 & Gotham & 2008 & USA & pandemic flu \\
\hline 73 & \begin{tabular}{|l|} 
Fineberg \\
\end{tabular} & 2008 & USA & pandemic flu \\
\hline 74 & Esposito & 2008 & EU & seasonal flu \\
\hline 75 & Dutta & 2008 & not specified & pandemic flu \\
\hline 76 & Wynia & 2006 & USA & pandemic flu \\
\hline 77 & Whitley & 2006 & USA & pandemic flu \\
\hline 78 & Torda & 2006 & Australia & pandemic flu \\
\hline 80 & Sencer & 2006 & USA & pandemic flu \\
\hline 81 & Schuklenk & 2006 & not specified & pandemic flu \\
\hline 82 & Roddy & 2006 & USA & \begin{tabular}{|l|} 
seasonal flu \\
\end{tabular} \\
\hline 83 & Ransom & 2006 & USA & pandemic flu \\
\hline 84 & Lewis & 2006 & USA & pandemic flu \\
\hline 85 & \begin{tabular}{|l|} 
Letts \\
\end{tabular} & 2006 & Australia & pandemic flu \\
\hline 86 & Krause & 2006 & USA & pandemic flu \\
\hline 87 & Kayman & 2006 & USA & pandemic flu \\
\hline 88 & Iton & 2006 & USA & both \\
\hline 89 & Hodge & 2006 & USA & pandemic flu \\
\hline 90 & Gronvall & 2006 & many in the world & pandemic flu \\
\hline 91 & Gazmararian & 2006 & USA & seasonal flu \\
\hline 92 & Garcia-Garcia & 2006 & many in the world & both \\
\hline 93 & Ferguson & 2006 & USA UK & pandemic flu \\
\hline 94 & Fedson & 2006 & many in the world & seasonal flu \\
\hline 96 & $\mathrm{Wu}$ & 2006 & not specified & seasonal flu \\
\hline 97 & Tam & 2005 & Canada & pandemic flu \\
\hline 98 & Seiguer & 2005 & USA & seasonal flu \\
\hline 99 & \begin{tabular}{|l} 
Schoch-Spana \\
\end{tabular} & 2005 & USA & \begin{tabular}{|l|} 
seasonal flu \\
\end{tabular} \\
\hline 100 & Oxford & 2005 & EU, others & pandemic flu \\
\hline 101 & Kotalik & 2005 & USA, Canada, UK & pandemic flu \\
\hline 102 & Kort & 2005 & Canada & pandemic flu \\
\hline 103 & Hadler & 2005 & USA, Canada & pandemic flu \\
\hline 104 & Fedson & 2005 & USA, Europe & pandemic flu \\
\hline 105 & Daems & 2005 & not specified & pandemic flu \\
\hline 107 & Gostin & 2004 & not specified & pandemic flu \\
\hline 108 & Doxtator & 2004 & Canada & pandemic flu \\
\hline 109 & Van Genugten & 2003 & Netherlands & pandemic flu \\
\hline 110 & Van Essen & 2003 & many in the world & seasonal flu \\
\hline 113 & Strikas & 2002 & USA & pandemic flu \\
\hline 114 & Gensheimer & 2002 & USA & pandemic flu \\
\hline 115 & Fock & 2002 & Germany & pandemic flu \\
\hline 117 & McDaid & 2001 & EU & seasonal flu \\
\hline 119 & Wunderli & 1997 & many in the world & \begin{tabular}{|l|} 
seasonal flu \\
\end{tabular} \\
\hline 121 & Hinman & 1997 & USA & \begin{tabular}{|l|} 
seasonal flu \\
\end{tabular} \\
\hline 124 & Nicholson & 1995 & USA, Europe & seasonal flu \\
\hline 125 & Tamblyn & 1994 & Canada & pandemic flu \\
\hline
\end{tabular}


Annex 2 - Categories of decisions established, main actors and information used

\begin{tabular}{|c|c|c|c|c|c|}
\hline Decision & Actors & $\begin{array}{l}\text { Current } \\
\text { Context }\end{array}$ & $\begin{array}{l}\text { Information } \\
\text { influencing }\end{array}$ & $\begin{array}{l}\text { Other factors } \\
\text { influencing } \\
\text { decisions }\end{array}$ & \# \\
\hline $\begin{array}{l}\text { VACCINE } \\
\text { STRATEGY } \\
\text { Vaccine virus } \\
\text { selection and } \\
\text { composition } \\
\text { (adjuvants...) }\end{array}$ & $\begin{array}{l}\text { WHO, GIRS, } \\
\text { manufacturers, } \\
\text { health authorities, } \\
\text { virological labs, } \\
\text { veterinarian }\end{array}$ & Seasonal & $\begin{array}{l}\text {-antigenic } \\
\text { history of } \\
\text { strains, } \\
\text { frequency and } \\
\text { type } \\
\text {-pathogenicity of } \\
\text { variants } \\
\text {-serological } \\
\text { studies }\end{array}$ & $\begin{array}{l}\text {-virus sharing } \\
\text { between countries } \\
\text {-influenza } \\
\text { surveillance }\end{array}$ & $\begin{array}{l}6,96,45,119 \\
29\end{array}$ \\
\hline$=$ & $=$ & Pandemic & $\begin{array}{l}\text {-antigenic } \\
\text { characteristics of } \\
\text { pandemic virus }\end{array}$ & $\begin{array}{l}\text {-logistics } \\
\text {-financial }\end{array}$ & 64,59 \\
\hline $\begin{array}{l}\text { VACCINE } \\
\text { STRATEGY } \\
\text { Vaccine } \\
\text { development }\end{array}$ & $\begin{array}{l}\text { Health } \\
\text { authorities, } \\
\text { manufacturers, } \\
\text { EMEA, FDA }\end{array}$ & Seasonal & $\begin{array}{l}\mathrm{x} * \\
\text { *no "seasonal" } \\
\text { articles } \\
\text { regarding } \\
\text { vaccine } \\
\text { development }\end{array}$ & $\mathrm{x}$ & $\mathrm{x}$ \\
\hline$=$ & $=$ & Pandemic & $\begin{array}{l}\text {-influenza } \\
\text { activity } \\
\text {-severity } \\
\text {-virological } \\
\text { information } \\
\text {-economic } \\
\text { studies }\end{array}$ & $\begin{array}{l}\text {-influenza } \\
\text { surveillance } \\
\text { - logistics } \\
\text { - regulatory } \\
\text { agencies approval } \\
\text {-financial }\end{array}$ & $\begin{array}{l}22,17,64,56, \\
83,105,90,15, \\
104\end{array}$ \\
\hline $\begin{array}{l}\text { VACCINE } \\
\text { STRATEGY } \\
\text { Vaccine } \\
\text { production } \\
\text { manufacturing }\end{array}$ & $\begin{array}{l}\text { CDC, } \\
\text { manufacturers, } \\
\text { health authorities }\end{array}$ & Seasonal & $\begin{array}{l}\text {-vaccine clinical } \\
\text { studies } \\
\text {-demographics }\end{array}$ & $\begin{array}{l}\text {-logisitics } \\
\text { - authorities } \\
\text { recommendations }\end{array}$ & $45,39,33$ \\
\hline$=$ & $=$ & Pandemic & $\begin{array}{l}\text {-standard } \\
\text { operating } \\
\text { procedures } \\
\text {-batch process } \\
\text { records }\end{array}$ & $\begin{array}{l}\text {-historical records } \\
\text {-influenza } \\
\text { surveillance } \\
\text {-financial } \\
\text {-skilled personnel } \\
\text {-timeline of } \\
\text { pandemics } \\
\text {-validation } \\
\text { procedures }\end{array}$ & $\begin{array}{l}62,68 \text {-both, } \\
90,86,105 \\
125\end{array}$ \\
\hline
\end{tabular}




\begin{tabular}{|c|c|c|c|c|c|}
\hline Decision & Actors & $\begin{array}{l}\text { Current } \\
\text { Context }\end{array}$ & $\begin{array}{l}\text { Information } \\
\text { influencing }\end{array}$ & $\begin{array}{l}\text { Other factors } \\
\text { influencing } \\
\text { decisions }\end{array}$ & \# \\
\hline $\begin{array}{l}\text { VACCINE } \\
\text { STRATEGY } \\
\text { Vaccine } \\
\text { prioritization, } \\
\text { rationing } \\
\text { (definition of } \\
\text { priority groups) } \\
\text { Mandatory } \\
\text { vaccination } \\
\text { (HCW) }\end{array}$ & $\begin{array}{l}\text { ECDC, EMA, } \\
\text { WHO, HSC, MS, } \\
\text { healthcare } \\
\text { providers }\end{array}$ & Seasonal & $\begin{array}{l}\text {-epidemiology } \\
\text { data } \\
\text {-vaccine clinical } \\
\text { studies } \\
\text {-ethics, } \\
\text { philosophy and } \\
\text { cultural grounds }\end{array}$ & $\begin{array}{l}\text {-logistics } \\
\text {-economic studies } \\
\text {-political } \\
\text { willingness } \\
\text {-local status (public } \\
\text { and stakeholders } \\
\text { opinion) }\end{array}$ & $\begin{array}{l}\text { 1, 33, 117, 46, } \\
37,69,9 \text {-both, } \\
99,124\end{array}$ \\
\hline$=$ & $=$ & Pandemic & $\begin{array}{l}\text {-epidemiology } \\
\text { data } \\
\text {-vaccine clinical } \\
\text { studies } \\
\text {-models } \\
\text {-ethics, law, } \\
\text { jurisdictions } \\
\text {-severity } \\
\text {-demographics } \\
\text { of pandemics } \\
\text {-virological data }\end{array}$ & $\begin{array}{l}\text {-logistics } \\
\text {-influenza } \\
\text { surveillance } \\
\text {-authorities } \\
\text { recommendations } \\
\text {-experts } \\
\text {-financial } \\
\text {-local status (public } \\
\text { and stakeholders } \\
\text { opinion) } \\
\text {-skilled personnel }\end{array}$ & $\begin{array}{l}3,4,51,71,89, \\
102,114,125, \\
53,87,23,76\end{array}$ \\
\hline $\begin{array}{l}\text { VACCINE } \\
\text { STRATEGY } \\
\text { Vaccine } \\
\text { purchasing, } \\
\text { ordering }\end{array}$ & $\begin{array}{l}\text { WHO, SAGE, } \\
\text { health authorities, } \\
\text { manufacturers, }\end{array}$ & Seasonal & $\begin{array}{l}\text {-demographics } \\
\text {-history of } \\
\text { previous years } \\
\text { demand }\end{array}$ & $\begin{array}{l}\text {-authorities } \\
\text { recommendations }\end{array}$ & 82,68 -both \\
\hline$=$ & $=$ & Pandemic & $\begin{array}{l}\text {-prescription pad } \\
\text { orders } \\
\text {-severity } \\
\text {-epidemiology } \\
\text {-economic } \\
\text { studies } \\
\text {-vaccine clinical } \\
\text { studies } \\
\text {-ethics, law } \\
\text {-demographics }\end{array}$ & $\begin{array}{l}\text {-influenza } \\
\text { surveillance } \\
\text {-local status (public } \\
\text { and stakeholders } \\
\text { opinion) } \\
\text {-experts } \\
\text {-regulatory } \\
\text { approval } \\
\text {-financial } \\
\text {-timeline of } \\
\text { pandemics } \\
\text {-guidelines }\end{array}$ & $\begin{array}{l}72,14,11,10 \\
25,74,89,125\end{array}$ \\
\hline $\begin{array}{l}\text { VACCINE } \\
\text { STRATEGY } \\
\text { Vaccine } \\
\text { distribution, } \\
\text { supply, allocation }\end{array}$ & $\begin{array}{l}\text { WHO, health } \\
\text { authorities, } \\
\text { manufacturers, } \\
\text { healthcare } \\
\text { providers }\end{array}$ & Seasonal & $\begin{array}{l}\text {-historical } \\
\text { records of } \\
\text { purchase } \\
\text {-logistics } \\
\text {-epidemiology } \\
\text {-vaccine clinical } \\
\text { studies }\end{array}$ & $\begin{array}{l}\text {-local status (public } \\
\text { and stakeholders } \\
\text { opinion) } \\
\text {-financial } \\
\text {-economic studies }\end{array}$ & $45,98,33,94$ \\
\hline
\end{tabular}




\begin{tabular}{|c|c|c|c|c|c|}
\hline Decision & Actors & $\begin{array}{l}\text { Current } \\
\text { Context }\end{array}$ & $\begin{array}{l}\text { Information } \\
\text { influencing }\end{array}$ & $\begin{array}{l}\text { Other factors } \\
\text { influencing } \\
\text { decisions }\end{array}$ & \# \\
\hline$=$ & $=$ & Pandemic & $\begin{array}{l}\text {-vaccine clinical } \\
\text { studies } \\
\text {-epidemiology } \\
\text {-models } \\
\text {-ethics, law } \\
\text { (willingness to } \\
\text { be vaccinated) }\end{array}$ & $\begin{array}{l}\text {-influenza } \\
\text { surveillance } \\
\text {-logistics } \\
\text {-economic studies } \\
\text {-historical records } \\
\text {-authorities } \\
\text { recommendations } \\
\text {-local status (public } \\
\text { and stakeholders } \\
\text { opinion) } \\
\text {-guidelines }\end{array}$ & $\begin{array}{l}15,16,24,51, \\
83,100,89, \\
87,83,105, \\
103,100,18\end{array}$ \\
\hline $\begin{array}{l}\text { VACCINE } \\
\text { STRATEGY } \\
\text { Vaccination } \\
\text { policy } \\
\text { implementation or } \\
\text { management }\end{array}$ & $\begin{array}{l}\text { WHO, ECDC, } \\
\text { health authorities, } \\
\text { healthcare } \\
\text { providers, } \\
\text { virological labs, } \\
\text { veterinarian }\end{array}$ & Seasonal & $\begin{array}{l}\text {-vaccine clinical } \\
\text { studies }\end{array}$ & $\begin{array}{l}\text {-epidemiology } \\
\text {-economic studies } \\
\text {-logistics }\end{array}$ & $\begin{array}{l}33,47,38- \\
\text { both, 34, 54, } \\
110,28,88,91 \\
121\end{array}$ \\
\hline $\begin{array}{l}= \\
\text { (mass vaccination } \\
\text { campaign) }\end{array}$ & $=$ & Pandemic & $\begin{array}{l}\text {-vaccine clinical } \\
\text { studies } \\
\text {-influenza } \\
\text { surveillance } \\
\text {-severity }\end{array}$ & $\begin{array}{l}\text {-epidemiology } \\
\text {-historical records } \\
\text {-experts } \\
\text {-local status (public } \\
\text { and stakeholders } \\
\text { opinion) } \\
\text {-financial } \\
\text {-models }\end{array}$ & $\begin{array}{l}2,8,22,32,86 \\
51,44,41,36 \\
30,73,15,80 \\
97\end{array}$ \\
\hline $\begin{array}{l}\text { Pandemic } \\
\text { Preparedness Plan }\end{array}$ & & Pandemic & & & $\begin{array}{l}5,7,12,13,19, \\
20,26,31,42, \\
48,49,50,52, \\
55,57,58,60, \\
61,63,66,67, \\
70,75,77,78, \\
81,84,85,92, \\
93,101,107, \\
108,109,113, \\
115,131,132\end{array}$ \\
\hline
\end{tabular}

